\title{
DEMOGRAFSKE I PROFESIONALNE KARAKTERISTIKE SREDNJOŠKOLSKIH UČITELJA U RELACIJI SA STAVOVIMA PREMA EDUKACIJSKOM UKLJUČIVANJU
}

\author{
NATAŠA VLAH ${ }^{1}$, PETRA MEĐIMOREC GRGURIĆ ${ }^{2}$, ĐANA BAFTIRI ${ }^{2}$ \\ ${ }^{1}$ Učiteljski fakultet, Rijeka, Republika Hrvatska. Kontakt: natasav@ufri.hr \\ ${ }^{2}$ Srednja škola - Centar za odgoj i obrazovanje, Zagreb, Republika Hrvatska
}

Primljeno: 9.11.2016.

Prihvaćeno: 28.5.2017.

Izvorni znanstveni rad

UDK: $37: 616.89-008.47$

Sažetak: Učitelji su ključni sudionici edukacijskog uključivanja prvenstveno zbog njihove spremnosti da prihvate učenike s teškoćama, o čemu uvelike ovisi uspješna realizacija edukacijskog uključivanja. Osnovni cilj rada je ispitati demografske $i$ profesionalne karakteristike učitelja strukovnih škola u iskazivanju stavova prema uključivanju učenika s intelektualnim teškoćama, specifičnim teškoćama učenja, problemima u ponašanju i ADHD poremećajem (dalje: stavovi). Ispitano je 568 učitelja (33\% muških, M=45 godina) iz 25 srednjih strukovnih škola u Zagrebu. Mjerena su četiri kriterijska stava: potreba za stručnom pomoći učiteljima u edukacijskom uključivanju, pesimizam za uspješno edukacijsko uključivanje, doživljaj kompetentnosti za edukacijsko uključivanje i problemi suradnje s roditeljima. Promatrani prostor predikcije za formiranje stavova bili su spol, dob, stručna sprema, predmet, ukupno radno iskustvo, radno iskustvo s učenicima s teškoćama i samoiskazane poteškoće u poučavanju učenika s teškoćama. Utvrđeni su elementi formiranja pozitivnih, odnosno negativnih stavova prema edukacijskom uključivanju učenika s intelektualnim teškoćama, specifičnim teškoćama učenja, poremećajima u ponašanju i ADHD-om. Potrebna su dodatna istraživanja i implementacija dobivenih rezultata u programe cjeloživotnog obrazovanja učitelja u školama s ciljem razvijanja veće spremnosti za rad s učenicima s teškoćama.

Ključne riječi: $A D H D$, problemi u ponašanju, srednja škola, stavovi učitelja, teškoće u učenju

\section{UVOD}

Učitelji ${ }^{1}$ su ključni čimbenik edukacijskog uključivanja ${ }^{2}$ (dalje: uključivanje/inkluzija) ponajprije zbog njihove spremnosti ili nespremnosti da prihvate učenike s teškoćama, ali i da utječu na pronalaženje najprimjerenijih oblika odgoja i obrazovanja, o čemu ovisi uspješna realizacija kako cilja, tako i procesa i organizacije uključivanja (Lewis i Doorlag, 1987; Mavrin-Cavor i Levandovski, 1991; Levin, 1992; Thousand, Villa i Nevin, 1994; Chazan, 1994; Igrić, Cvitković i Wagner Jakob, 2009; Bartolac, 2013; Florian, 2010; Florian i Linklater, 2010). Obzirom da rade neposredno u nastavi i da se njihovo praktično iskustvo odnosi na odgoj i obrazovanje u cjelini, učitelji imaju bitnu ulogu u provedbi učinkovite inkluzije (Schmidt i Čagran, 2014) te nose najveći teret i odgovornost za uspješnu provedbu uključivanja. Istovremeno, iako zakonska regulativa propisuje stručnu pomoć, ta pomoć, osim u pojedinim regijama zemlje, nije u potpunosti osigurana (Kiš-Glavaš, Nikolić i Igrić, 1997; Skočić-Mihić, Gabrić i Bošković, 2016). Vrlo je malo zaposlenih stručnjaka edukacijsko-rehabilitacijskog profila (logopedi, socijalni pedagozi i rehabilitatori) na radnim mjestima stručnog suradnika u strukovnim školama. Unatoč postojećim zakonskim preduvjetima za osnivanje centara potpore u našoj zemlji

1 U skladu s određenjem u Strategiji znanosti, obrazovanja i tehnologije (2014.) u Okviru nacionalnoga standarda kvalifikacija za učitelje u osnovnim i srednjim školama sve se osobe odgovorne za poučavanje i učenje u osnovnoškolskome i srednjoškolskome obrazovanju nazivaju zajedničkim nazivom „učitelj“ (prema Preporuci o statusu učitelja - Recommendation Concerning the Status of Teachers, UNESCO, Pariz, 1966.). Naziv „učitelj“” odnosi na osobe obaju spolova http://nvoo.hr/?page_id=391 (pribavljeno 13.4.2017.)

2 Pojam edukacijsko uključivanje podrazumijeva obrazovanje za sve, za razliku od pojma integracije. Provedba edukacijskog uključivanja (odnosno edukacijske inkluzije) moguća je samo uz društvene promjene, i to od državne razine do razine svake lokalne škole (Igrić, 2015). 
(Pravilnik o osnovnoškolskom i srednjoškolskom odgoju i obrazovanju učenika s teškoćama u razvo$j u, N N$ 24/2015) do trenutka prijave ovog rada još nisu osnovani. Autorice ovog rada polaze od uvjerenja da bi se preustrojem posebnih srednjoškolskih ustanova u centre potpore inkluziji u značajnoj mjeri olakšala i unaprijedila provedba edukacijske inkluzije učenika s teškoćama u redovne srednje strukovne škole. Potrebe za potporom učiteljima u strukovnim školama postoje jer, kada je riječ o uključivanju učenika s intelektualnim teškoćama, specifičnim teškoćama učenja, problemima u ponašanju i ADHD poremećajima, učitelji u strukovnim školama Grada Zagreba izražavaju veliku potrebu za stručnom podrškom u provedbi inkluzije, imaju srednje visok doživljaj vlastitih kompetencija za rad s navedenom populacijom učenika i srednje pesimističan stav za uspješno uključivanje te su im visoko iskazani problemi u suradnji s roditeljima učenika s teškoćama (Međimorec Grgurić i sur., 2014). Slijedom svega navedenog, problem ovog rada je dodatno analizirati što učiteljima u strukovnim školama Grada Zagreba predstavlja poteškoću pri poučavanju učenika s teškoćama i može li se temeljem različitih demografskih i profesionalnih obilježja učitelja i njihovih iskazanih poteškoća u poučavanju učenika s teškoćama predvidjeti kakvi će biti njihovi stavovi prema inkluziji. Aplikativna je svrha predlaganje elemenata subjektivnih i objektivno-organizacijskih ${ }^{3}$ poboljšanja u školi te dodatnih edukacija za učitelje radi uspješnog uključivanja učenika s navedenim teškoćama.

\section{INTELEKTUALNE TEŠKOĆE, SPECIFIČNE TEŠKOĆE UČENJA, PROBLEMI U PONAŠANJU I ADHD}

U prvom stavku članka 65. Zakona o odgoju i obrazovanju u osnovnoj i srednjoj školi (2008) koristi se termin učenici s teškoćama te se propisuje da su to učenici (i) s teškoćama u razvoju, (ii) učenici s teškoćama u učenju, problemima u ponašanju i emocionalnim problemima te (iii) učenici s teškoćama uvjetovanim odgojnim, socijalnim, ekonomskim, kulturalnim i jezičnim čimbenicima. Pravilnik o osnovnoškolskom $i$ srednjoškolskom odgoju i obrazovanju učenika s teškoćama u razvoju (2015) propisuje kriterije i procedure utvrđivanja primjerenog oblika školovanja za učenike s teškoćama u razvoju. Iz prakse je poznato kako se rješenja o primjerenom obliku školovanja uglavnom izdaju učenicima čije su teškoće dijagnosticirane i organski uvjetovane (npr. disleksija, ADHD), a učenici s blažim (ili nedijagnosticiranim) intelektualnim i/ili teškoćama u učenju, problemima u ponašanju i emocionalnim problemima te učenici s teškoćama uvjetovanim odgojnim, socijalnim, ekonomskim, kulturalnim i jezičnim čimbenicima, prema iskustvima praktičara u Hrvatskoj i autorica ovog rada, često ostaju neobuhvaćeni razumnom prilagodbom u nastavi koja im, nerijetko također treba radi socijalne integracije u zajednicu (Bouillet, 2010). Stoga, neovisno o tome imaju li rješenja o primjerenom obliku školovanja ili nemaju, u ovom je radu posredan fokus upravo na učenike kod kojih su prisutne intelektualne teškoće i/ili specifične teškoće učenja i/ ili problemi u ponašanju i/ili ADHD poremećaj. Navedene teškoće autorice ovog rada ubrajaju u „nevidljive teškoće“ koje često nisu adekvatno i na vrijeme prepoznate. Prilagodbe u školskom okruženju koje su potrebne ovim učenicima često nisu uvedene ili su neadekvatne. Poznato je da se učitelji osjećaju najmanje spremni za inkluziju učenika s kognitivnim teškoćama i problemima u ponašanju, dok lakše prihvaćaju inkluziju učenika s tjelesnim ili slušnim teškoćama (Salend i Dunahey, 1999) i više podržavaju inkluziju učenika sa senzornim ili tjelesnim teškoćama (Avramidis i Norwich, 2012), dok se opiru inkluziji učenika sa socijalnim, emocionalnim ili poremećajima u ponašanju (Lifshitz i sur., 2004). Istovremeno, većina učitelja smatra kako su im upravo učenici s emocionalnim teškoćama i problemima u ponašanju te učenici s kombinacijom teškoća u učenju i emocionalnih teškoća s problemima u ponašanju najveći izazov za uspješno uključivanje u redovne uvjete obrazovanja (Bowman, 1986; Clough i Lindsay, 1991; Lifshitz i sur., 2004; Mac Farlane i Woolfson, 2013, prema Schmidt i Vrhovnik, 2015). Višestruke teškoće su prema Sekušak-Galešev (2008) najčešće utvrđivane u osnovnim zagrebačkim školama, a autorica kod učenika utvrđuje prisutnost emocionalnih teškoća (37\%), organsku disfunkciju SŽS-a

3 Ljubić i Kiš Glavaš (2003) primjećuju da su u srednjim školama objektivno-organizacijske pretpostavke slabije nego u osnovnim školama. 
(37\%), teškoće učenja neodređenog tipa, intelektualne teškoće (34\%), teškoće čitanja i pisanja (28\%) i ADHD (23\%). Opravdano je očekivati da će se ove teškoće ili njihov dio manifestirati i u nastavku školovanja te da će se usljed njih kod učenika možda razviti niže samopoštovanje i stupanj anksioznosti. Naime, $40 \%$ djece s teškoćama u učenju sekundarno razvija socijalne, emocionalne i ponašajne teškoće (Igrić i sur, 2009).

Možemo se zapitati i o drugim rizicima koji utječu na uspješnost pri njihovom uključivanju. Učitelji nerijetko „kažnjavaju“ učenike nerazumijevanjem iskazanim lošim ocjenama te njihovim izdvajanjem iz redovnih i upućivanjem u neke druge oblike školskog programa (Kuvač i Vrancaš, 2003). Također, na jednak način pristupaju učenicima koji imaju ADHD i onima koji ga nemaju, a to govori o nepoznavanju specifičnosti te djece kao i izostanku pedagoškog planiranja strategija poučavanja, što je svakako potrebno, ako se govori o inkluzivnom odgoju i obrazovanju (Kudek Mirošević i Opić, 2011) dok se problemi vezani uz snižene intelektualne sposobnosti učenika s teškoćama, prepoznaju kao jedan od čimbenika negativnijih stavova učitelja prema inkluzivnom obrazovanju (Đević, 2009). Brojna istraživanja su pokazala kako poučavanje učenika s emocionalnim teškoćama, poremećajima u ponašanju i teškoćama pažnje i hiperaktivnosti predstavlja najveći izazov u usporedbi s učenicima s drugim vrstama teškoća jer postoji potreba neprestanog dodatnog ulaganja u osnaživanje vještina i kompetencija učitelja koji rade $\mathrm{s}$ učenicima s navedenim teškoćama $\mathrm{u}$ obrazovnom sustavu (Billingsley, Fall i Williams, 2006). Sve navedeno upućuje na opravdanost istraživanja osobitosti demografskih i profesionalnih karakteristika učitelja u poučavanju učenika $\mathrm{s}$ intelektualnim teškoćama, specifičnim teškoćama učenja, problemima u ponašanju i ADHD poremećajima.

\section{ŠTO KOD UČITELJA FORMIRA POZITIVAN STAV ZA INKLUZIJU?}

Nekoliko je desetljeća poznato kako na stavove učitelja utječu brojni čimbenici: informiranost učitelja, heterogenost populacije učenika s teškoćama, vrste teškoća, obilježja samih učenika, stupanj uključenosti, vanjski izgled učenika, spol učeni- ka (Stančić, 1985; Avramidis i Norwich, 2002; Ivančić i Stančić, 2013; Kiš-Glavaš i Cvitković, 2014), obilježja osobnosti i stupanj informiranosti učitelja o učeniku (Fulgosi-Masnjak, 2013), način poučavanja i razina sigurnosti učitelja u izbor odgovarajućih metoda podučavanja djece s teškoćama (Brook, Watemberg i Geva, 2000), iskustvo rada s učenicima s teškoćama (Van Reusen, Shoho i Barker, 2001), pretjerano povećan obujam (brojnost) razreda, primjena zastarjelih i neučinkovitih tehnika, metoda i strategija prema učeniku s teškoćama prilikom učenja te potreba za pružanjem veće podrške i ohrabrivanja za obavljanje ovog posla (Khan, 2012, prema Schmidt i Vrhovnik, 2015). Zadovoljstvo ili nezadovoljstvo uvjetima rada je također bitan element formiranja stavova prema uključivanju (Dulčić i Bakota, 2008), pri čemu su najveći nedostatci za uspješno uključivanje: neodgovarajuća i nedostatna nastavna pomagala $\mathrm{i}$ didaktički materijal, pretjerana sadržajna opširnost i jezična složenost udžbenika, priručnika i radnih materijala, nedostatnost i nepravovremenost stručnog usavršavanja učitelja. Sve navedeno govori o potrebi veće usmjerenosti na otklanjanje ovih prepreka za uspješno edukacijsko uključivanje. Većina srednjoškolskih učitelja su pripremljeni kao predmetni stručnjaci i mnogi nisu voljni prilagođavati se pojedinačnim učenicima, npr. koristiti alternativni kurikulum, prilagođeno vrednovanje, alternativne programe (Van Reusen, Shoho i Barker, 2001), pa se može reći kako planiraju i vode nastavu usmjereno prema prosječnom učeniku s evaluacijom koja se zasniva na prosječnom funkcioniranju. Isti autori upozoravaju na činjenicu kako se od suvremenih srednjoškolskih programa očekuje da pripreme učenike za kompleksne zahtjeve društva, dok se vrednovanje vrši preko standardiziranih testova i matura, što učenike s teškoćama dovodi u specifičan položaj. Sve navedeno, zajedno s očekivanjima uključivanja učenika s teškoćama, predstavlja srednjoškolskim učiteljima veliki pritisak (kako države tako i lokalne uprave te državnih agencija i raznih udruga) kako bi ostvarili te ciljeve. Čimbenici koji se povezuju s pozitivnijim stavovima učitelja prema uključivanju su dostupnost stručne potpore na razini razrednog odjela i na razini škole u smislu prilagođenih materijala za poučavanje, dovoljno unaprijed izrađenih prilagođenih materijala za poučavanje te manji broj 
učenika u razrednim odjelima (Center i Ward, 1987, Clough i Lindsay, 1991, Myles i Simpson, 1989, prema Avramidis i Norwich, 2002; Scruggs i Mastopieri, 1996; Schmidt i Vrhovnik, 2015). Uz pravilnu edukaciju učitelj će biti u mogućnosti pravilno odabrati način poučavanja te steći sigurnost u izbor odgovarajućih metoda poučavanja djece $\mathrm{s}$ teškoćama (Thomas, 1985, prema Igrić i sur., 2014) što se smatra jednim od bitnih elemenata osjećaja kompetentnosti te formiranja i učvršćivanja pozitivnih stavova prema uključivanju. Procjena individualnih potreba i izrada individualiziranih odgojno-obrazovnih programa (IOOP-a) neizostavna je u uključivanju učenika s teškoćama, a svi učitelji nisu za to odgovarajuće pripremljeni (Ivančić i Stančić, 2013; Stančić, Horvatić i Nikolić, 2011). Opravdano je očekivati da će nabrojani deficiti znanja i vještina biti bitan čimbenik u formiranju negativnih stavova prema uključivanju.

Stavovi koji proizlaze iz uspješne komunikacije s roditeljima učenika s teškoćama su osobito važni za dalju provedbu inkljuzije. Konstruktivna komunikacija učitelja s roditeljima je važna za sve učenike (Škutor, 2014), a osobito kod učenika s teškoćama jer predstavlja nezaobilazan element uspješnog uključivanja. Može se reći da se učitelji moraju nositi s ovim izazovom koji im je u nekim slučajevima i najteži. Među najvažnijim preprekama u ostvarivanju suradnje s roditeljima su krutost stručnjaka i nedostatak njihove fleksibilnosti u uspostavljanju odnosa s roditeljima, zbog čega roditelji gube povjerenje u sustav i institucije (Lord-Nelson, Summers i Turnbull, 2004). Partnerstvo s roditeljima doprinosi učinkovitijim promjenama kod samih učenika i stvaranju kulture inkluzivne škole (Ivančić i Stančić, 2004; 2013) pa je i ovaj segment važan u pripremi učitelja za uspješno uključivanje učenika u redovni odgojno-obrazovni sustav.

Učitelji ženskog spola imali su u prethodnim istraživanjima pozitivnije stavove prema uključivanju učenika i prema osobama s teškoćama u razvoju u odnosu na ispitanike muškog spola (Igrić i sur., 2009; Kiš-Glavaš i sur., 1997), a postoje i istraživanja koja ne ukazuju na razlike u stavovima u odnosu na spol ispitanika (Beh-Pajooh, 1992, Berryman, 1989, Leyser i dr., 1994, prema Avramidis i Norwich, 2002). Uočene su razlike u stavovima učitelja prema uključivanju obzirom na dob (Kiš-Glavaš i sur., 1997; Skočić-Mihić i sur., 2016) pri čemu mlađi učitelji imaju pozitivnije stavove. Slično je i s duljinom radnog staža - što je duži, stavovi su negativniji (Skočić-Mihić i sur, 2016; Avramidis i Norwich, 2002). Učitelji $\mathrm{s}$ kraćim radnim stažem te najčešce i mladi učitelji, koji su dobili bolju dodiplomsku potporu, a i dodatno su educirani, bolje shvaćaju prednosti i ciljeve uključivanja (Sodak i sur., 1998, prema Igrić i sur., 2014).

\section{CILJEVI I HIPOTEZE}

Osnovni cilj rada je bio ispitati demografske i profesionalne karakteristike učitelja strukovnih škola u iskazivanju stavova prema uključivanju učenika s intelektualnim teškoćama, specifičnim teškoćama učenja, problemima u ponašanju i ADHD poremećajem (dalje: stavovi). Specifični su ciljevi rada utvrditi (i) samoiskazane poteškoće poučavanja učenika s teškoćama, (ii) povezanost stavova s obilježjima učitelja (spol, dob, stručna sprema, radno iskustvo, radno iskustvo u radu s učenicima s teškoćama) i samoiskazanim poteškoćama poučavanja učenika s teškoćama, (iii) doprinos obilježja učitelja (spol, dob, stručna sprema, radno iskustvo, radno iskustvo u radu s učenicima s teškoćama) i samoiskazanih poteškoća poučavanja učenika s teškoćama na stavove i (iv) razlike u stavovima između učitelja pojedinih predmeta (grupa predmeta) koje učitelji poučavaju. Četiri su stava koja se promatraju kao kriteriji u radu: potreba za stručnom pomoći učiteljima u inkluziji, pesimizam za uspješnu inkluziju, doživljaj kompetentnosti za inkluziju, problemi suradnje s roditeljima. Hipotezu koja bi proizlazila iz prvog specifičnog cilja se ne može formulirati jer se u dostupnoj literaturi ne može pronaći nedvosmislena teorijska utemeljenost za valjanu pretpostavku. No, slijedom analizirane teorije $\mathrm{u}$ uvodnim poglavljima, pretpostavlja se da:

H1 postoji povezanost između stavova i obilježja učitelja (spol, dob, stručna sprema, radno iskustvo, radno iskustvo u radu s učenicima s teškoćama) te stavova i samoiskazanih poteškoća poučavanja učenika s teškoćama.

H2 ženski spol, mlađa dob, više iskustva u radu $\mathrm{s}$ učenicima $\mathrm{s}$ teškoćama te odsutnost samo- 
Nataša Vlah, Petra Međimorec Grgurić, Đana Baftiri: Demografska i profesionalna obilježja srednjoškolskih nastavnika u relaciji sa...

iskazanih poteškoća poučavanja učenika s teškoćama doprinosi povoljnijim stavovima.

H3 učitelji koji predaju strukovne predmete i praksu imaju nepovoljnije stavove od ostalih učitelja ostalih predmeta.

\section{METODE RADA}

\section{Sudionici istraživanja}

$\mathrm{U}$ istraživanju je sudjelovalo $\mathrm{N}=568$ učitelja (33\% muških) iz 25 srednjih strukovnih škola u Gradu Zagrebu ${ }^{4}, 5$ od kojih 22\% izjavljuje kako uopće nije imalo iskustva u radu s učenicima s teškoćama.

Dob $(M=45)$ je bila u rasponu od 23 do 64 godina. $0=$ muški, $1=$ ženski.

Zastupljenost različitih dobnih skupina učitelja $\mathrm{u}$ istraživanju je bila podjednaka (tablica 1).

S obzirom na stručnu spremu koju su učitelji stekli, 87\% ih ima VSS (tablica 2).

Podjednako su u istraživanju zastupljeni ispitanici s različitim trajanjem ukupnog radnog iskustva (tablica 3).

Preko $50 \%$ ispitanika uopće nije imalo iskustva u radu s učenicima s teškoćama ili su imali od 0-4 godine takvog iskustva (tablica 4).

Gotovo $40 \%$ ispitanika u istraživanju predaju strukovni predmet i/ili vode praktičnu nastavu. Učitelji ostalih nastavnih predmeta zastupljeni su podjednako (tablica 5).

\section{Mjerni instrumenti}

(i)Upitnik o poteškoćama u poučavanju učenika $s$ teškoćama je u fokus grupi stručnjaka edukacijsko-rehabilitacijskog profila konstruiran za potrebe ovog istraživanja. Učitelji su na univarijatnim česticama samoiskazivali zadaju li im pojedini didaktičko-metodički zahtjevi ili specifične situacije poteškoću u njegovom/njezinom radu s učenicima s teškoćama. Odgovarali su na nedovršenu rečenicu: U mom radu s učenicima s teškoćama poteškoće mi zadaje... pri čemu su mogli odgovoriti s DA/NE (varijable su vidljive u tablici 6).
Tablica 1. dob učitelja

\begin{tabular}{|l|c|c|}
\hline DOB ISPITANIKA & N & \% \\
\hline od 23 do 29 godina & 44 & $7.7 \%$ \\
\hline od 30 do 34 godine & 68 & $12 \%$ \\
\hline od 35 do 39 godina & 47 & $8.3 \%$ \\
\hline od 40 do 44 godine & 74 & $13 \%$ \\
\hline od 45 do 49 godina & 83 & $14.6 \%$ \\
\hline od 50 do 54 godine & 87 & $15.3 \%$ \\
\hline od 55 do 59 godina & 75 & $13.2 \%$ \\
\hline od 60 i više godina & 90 & $15.8 \%$ \\
\hline
\end{tabular}

Tablica 2. stručna sprema učitelja

\begin{tabular}{|l|c|c|}
\hline STRUČNA SPREMA & N & \% \\
\hline SSS (4. ili 5. stupanj) & 37 & $6.5 \%$ \\
\hline Apsolvent & 1 & $0.2 \%$ \\
\hline Viša stručna sprema & 21 & $3.7 \%$ \\
\hline VSS & 494 & $87 \%$ \\
\hline Magistar znanosti & 13 & $2.3 \%$ \\
\hline Nije upisano & 2 & $0.4 \%$ \\
\hline
\end{tabular}

Tablica 3. radno iskustvo učitelja

\begin{tabular}{|l|c|c|}
\hline RADNO ISKUSTVO & $\mathbf{N}$ & $\mathbf{\%}$ \\
\hline 0-4 godine & 76 & $13.4 \%$ \\
\hline $5-9$ godina & 74 & $13 \%$ \\
\hline 10-14 godina & 62 & $10.9 \%$ \\
\hline 15-19 godina & 67 & $11.8 \%$ \\
\hline 20-24 godina & 84 & $14.8 \%$ \\
\hline $25-29$ godina & 61 & $10.7 \%$ \\
\hline $30-34$ godina & 67 & $11.8 \%$ \\
\hline $35-39$ godina & 52 & $9.2 \%$ \\
\hline 40 i više godina & 25 & $4.4 \%$ \\
\hline
\end{tabular}

Tablica 4. radno iskustvo učitelja u radu s učenicima s teškoćama

\begin{tabular}{|l|c|c|}
\hline $\begin{array}{l}\text { RADNO ISKUSTVO U RADU S } \\
\text { UČENICIMA S TEŠKOĆAMA }\end{array}$ & N & \% \\
\hline bez iskustva & 125 & $22 \%$ \\
\hline 0-4 godine & 197 & $34.7 \%$ \\
\hline 5-9 godina & 74 & $13 \%$ \\
\hline 10-14 godina & 60 & $10.6 \%$ \\
\hline 15-19 godina & 30 & $5.3 \%$ \\
\hline 20-24 godina & 38 & $6.7 \%$ \\
\hline 25-29 godina & 18 & $3.2 \%$ \\
\hline $30-34$ godina & 17 & $3 \%$ \\
\hline $35-39$ godina & 9 & $1.6 \%$ \\
\hline
\end{tabular}

4 Odabir ovakvog uzorka ispitanika je iz razloga što se, s obzirom na navedene vrste teškoća učenika, oni većinom upisuju u programe trogodišnjih i dijelom četverogodišnjih srednjih strukovnih škola.

5 Od svih škola u istraživanju jedna je imala zaposlenog rehabilitatora i na tri škole je radila jedna socijalna pedagoginja kao stručni suradnik. 
Tablica 5. predmet koji učitelji predaju

\begin{tabular}{|l|c|c|}
\hline NASTAVNI PREDMET & N & \% \\
\hline Hrvatski jezik & 59 & $10.4 \%$ \\
\hline Strani jezik & 70 & $12.3 \%$ \\
\hline $\begin{array}{l}\text { Prirodni predmeti (Matematika, } \\
\text { Informatika, Statistika, Računalstvo, } \\
\text { Fizika, Biologija, Kemija) }\end{array}$ & 98 & $17.3 \%$ \\
\hline $\begin{array}{l}\text { Društveni predmeti (Geografija, Povijest, } \\
\text { Politika i gospodarstvo, Vjeronauk, Etika, } \\
\text { Sociologija, Logika, Psihologija) }\end{array}$ & 66 & $11.6 \%$ \\
\hline Tjelesna i zdravstvena kultura & 19 & $3.3 \%$ \\
\hline Strukovni predmeti & 167 & $29.4 \%$ \\
\hline Praktična nastava & 37 & $6.5 \%$ \\
\hline $\begin{array}{l}\text { Strukovni predmeti i praktična nastava } \\
\text { (kombinacija) }\end{array}$ & 21 & $3.7 \%$ \\
\hline $\begin{array}{l}\text { Neka druga kombinacija nastavnih } \\
\text { predmeta }\end{array}$ & 17 & $3 \%$ \\
\hline Nije upisano & 14 & $2.5 \%$ \\
\hline
\end{tabular}

(ii) Skalom stavova o uspješnosti inkluzije (SUI) (Međimorec Grgurić i sur., 2014) mjereni su stavovi učitelja u redovnim strukovnim školama. Učitelji su odgovarali na skali Likertovog tipa (od 1= u potpunosti se slažem do $5=$ uopće se ne slažem). Radi se o skali koja mjeri 4 pouzdane dimenzije promatrane kao kriterijske dimenzije. Prva je potreba za stručnom pomoći učiteljima u inkluziji $(\alpha=.77 ; \mathrm{N}=5$; primjer varijable: Prihvatio bih učenike s teškoćama kada bih imao pomoć oko izrade i provedbe progra$m a$ ). Druga je dimenzija pesimizam za uspješnu inkluziju ( $\alpha=.77 ; \mathrm{N}=6$; primjer varijable: Učenici $s$ teškoćama trebali bi se obrazovati u posebnim ustanovama). Treća dimenzija je doživljaj kompetentnosti za inkluziju $(\alpha=.78 ; \mathrm{N}=7$; primjer varijable: Posjedujem dovoljna znanja o učenicima sa specifičnim teškoćama u učenju (disgrafija, disleksija, diskalkulija). Četvrta dimenzija je problemi suradnje s roditeljima $(\alpha=.72 ; \mathrm{N}=3$; primjer varijable: Roditelji učenika s teškoćama u razvoju često skrivaju pravu sliku o teškoćama djeteta).

(iii)Upitnikom demografska i profesionalna obilježja učitelja prikupljeni su podaci o spolu, dobi, stručnoj spremi, radnom iskustvu, radnom iskustvu $\mathrm{u}$ radu $\mathrm{s}$ učenicima $\mathrm{s}$ teškoćama i predmetu koji učitelj predaje.

\section{Prikupljanje i obrada podataka}

Istraživanje je provedeno tijekom šk. godine 2012./2013. godine u istraživačkom projektu iz kojega je proizašao rad Međimorec Grgurić i sur., (2015) i u kojem je detaljno opisan postupak prikupljanja podataka. Učitelji su u prigodnom uzorku dobrovoljno i anonimno ispunjavali integrirani Upitnik za učitelje s opisanim mjernim instrumentima. U odnosu na broj poslanih upitnika, ukupan povrat valjano ispunjenih upitnika iznosio je $60 \%$. Za potrebe realizacije prvog specifičnog cilja podaci su obrađeni deskriptivnom analizom. Kako bi se testirala prva hipoteza korištene su KendallTau rang korelacije jer su podaci mjereni skalama mjernih mehanizama koji imaju samo svojstvo identiteta i ranga, a nemaju svojstvo aditivnosti (Mejovšek, 2013). Provedene su četiri linearne regresijske analize radi provjere druge hipoteze. Na kraju, za testiranje četvrtog cilja i treće hipoteze korištena je ANOVA jer su se promatrale razlike u varijanci linearno raspodjeljenih odgovora između više grupa ispitanika, uz Bonferroni Post Hoc test (test koji omogućuje uvid u statistički značajno razlikovanje grupa uz korekciju za kontrolu Alpha pogreške pri višestrukim usporedbama u paru).

\section{REZULTATI}

\section{Deskriptivni podaci za poteškoće u radu $s$ učenicima s teškoćama}

Tablica 6. Odgovori učitelja o poteškoćama u poučavanju učenika s teškoćama

\begin{tabular}{|l|c|c|c|c|}
\hline & NE & & DA & \\
\cline { 2 - 5 } & Aps. & \% & Aps. & \% \\
\hline $\begin{array}{l}\text { prilagodba sadržaja pojedinom } \\
\text { učeniku }\end{array}$ & 349 & 61.4 & 219 & 38.6 \\
\hline izrada liste procjene i IOOP-a & 394 & 69.4 & 174 & 30.6 \\
\hline ocjenjivanje učenika s teškoćama & 415 & 73.1 & 153 & 26.9 \\
\hline kontakt s učenikom s teškoćama & 521 & 91.7 & 47 & 8.3 \\
\hline $\begin{array}{l}\text { broj učenika u razrednom } \\
\text { odjeljenju }\end{array}$ & 214 & 37.7 & 354 & 62.3 \\
\hline $\begin{array}{l}\text { izostanak stručne pomoći. } \\
\text { psihologa, edukacijskog } \\
\text { rehabilitatora i sl. }\end{array}$ & 353 & 62.1 & 215 & 37.9 \\
\hline $\begin{array}{l}\text { nedostatak udžbenika za učenike } \\
\text { s teškoćama }\end{array}$ & 348 & 61.3 & 220 & 38.7 \\
\hline
\end{tabular}

Za gotovo dvije trećine učitelja poteškoću u poučavanju predstavlja broj učenika u razredu (tablica 6). Za jednu trećinu učitelja u promatranim školama poteškoću u radu predstavlja prilagodba sadržaja pojedinom učeniku, nedostatak udžbenika 
za učenike s teškoćama, izostanak stručne pomoći psihologa, edukacijskog rehabilitatora i sl. te izrada liste procjene i IOOP-a. Jedna četvrtina učitelja ima problem kod ocjenjivanja učenika s teškoćama. Manje od jedne desetine učitelja smatra kontakt s učenicima poteškoćom.

Analiza utvrđene korelacijske matrice pokazuje da je, od očekivanih 48 povezanosti između stavova učitelja i njihovih obilježja/poteškoća u poučavanju učenika, utvrđeno 17 povezanosti (tablica 7) koje su niske, ali značajne. Mjerni mehanizam tipa Likertove skale je suprotnog smjera od očekivanog (od $1=u$ potpunosti se slažem do 5= uopće se ne slažem) pa to treba imati u vidu pri čitanju povezanosti u tablicama 7. i 8 . Potreba za stručnom pomoći učiteljima u inkluziji pozitivno je povezana sa ženskim spolom is izraženim poteškoćama u poučavanju učenika $\mathrm{s}$ teškoćama: u prilagodbi sadržaja, pri izradi liste procjene i IOOP-a te izostankom stručne pomoći. Više potrebe za stručnom pomoći iskazuju učitelji ženskog spola i učitelji koji imaju izražene poteškoće u poučavanju učenika s teškoćama ( u prilagodbi sadržaja, pri izradi liste procjene $i$ IOOP-a). Pesimizam za uspješnu inkluziju pozitivno je povezan sa ženskim spolom, većom dobi učitelja, nižom stručnom spremom, većim radnim iskustvom i s izraženim poteškoćama u poučavanju učenika s teškoćama: u prilagodbi sadržaja i kontaktu s učenicima s teškoćama. Izraženiji pesimizam za uspješnu inkluziju iskazuju učitelji ženskog spola, stariji učitelji, učitelji s nižom stručnom spremom, oni s većim radnim iskustvom te učitelji koji imaju izražene poteškoće u poučavanju učenika s teškoćama ( u prilagodbi sadržaja i kontaktu s učenicima s teškoćama). Doživljaj kompetentnosti za uključivanje pozitivno je povezan s nižom stručnom spremom, većim radnim iskustvom u radu s učenicima $s$ teškoćama $i$ nepostojanjem poteškoće $u$ radu u vidu izostanka stručne pomoći. Višu razinu doživljaja kompetentnosti za uključivanje iskazali su učitelji s nižom stručnom spremom, većim radnim iskustvom u radu $\mathrm{s}$ učenicima s teškoćama te oni kojima ne nedostaje stručna pomoć. Problemi suradnje s roditeljima pozitivno su povezani s višom dobi učitelja, većim radnim iskustvom i većim radnim iskustvom $\mathrm{s}$ učenicima $\mathrm{s}$ teškoćama te iskazanim poteškoćama u poučavanju učenika s teškoćama: većim brojem učenika u razrednom odjelu i izostankom stručne pomoći. Stariji učitelji, učitelji $\mathrm{s}$ većim ukupnim radnim iskustvom i većim radnim iskustvom $\mathrm{s}$ učenicima $\mathrm{s}$ teškoćama te oni $\mathrm{s}$ iskazanim poteškoćama u poučavanju učenika s teškoćama (veći broj učenika u razrednom odjelu i izostanak stručne pomoći) češće iskazuju probleme suradnje s roditeljima učenika s teškoćama. Utvrđene povezanosti uglavnom, osim u slučaju pozitivne povezanosti ženskog spola i pesimizma za inkluziju, potvrđuju prethodna istraživanja. Budući da dvosmjerne korelacije ne daju informaciju o prediktorskom doprinosu značajnih varijabli na kriterij, potrebno je analizirati vrijednosti regresijske analize.

Tablica 7. Kendal-tau rang korelacije demografskih i profesionalnih obilježja učitelja s njihovm stavovima

\begin{tabular}{|l|c|c|c|c|}
\hline & $\begin{array}{c}\text { potreba za stručnom } \\
\text { pomoći učiteljima u } \\
\text { inkluziji }\end{array}$ & $\begin{array}{c}\text { pesimizam za } \\
\text { uspješnu inkluziju }\end{array}$ & $\begin{array}{c}\text { doživljaj } \\
\text { kompetentnosti za } \\
\text { inkluziju }\end{array}$ & $\begin{array}{c}\text { problemi } \\
\text { suradnje s } \\
\text { roditeljima }\end{array}$ \\
\hline spol & $\mathbf{- . 1 2 * *}$ & $\mathbf{- . 0 8 *}$ & .07 & -.03 \\
\hline dob & -.00 & $-.17 * *$ & .02 & $-.13 * *$ \\
\hline stručna sprema & -.01 & $\mathbf{. 0 8 *}$ & $.09 *$ & .05 \\
\hline radno iskustvo & .00 & $\mathbf{- . 1 6 * *}$ & .03 & $-.14 * *$ \\
\hline radno iskustvo s uč. s teškoćama & .03 & -.05 & $-.10 * *$ & $-.07 *$ \\
\hline prilagodba sadržaja & $\mathbf{- . 1 1 * *}$ & $-.11^{* *}$ & .06 & -.06 \\
\hline IOOP &.$- .11 *$ & -.01 & .04 & -.05 \\
\hline ocjenjivanje & -.01 & -.02 & .03 & -.07 \\
\hline kontakt & -.01 & $-.11 *$ & .05 & -.04 \\
\hline broj učenika & -.04 & -.03 & -.02 & $-.07 *$ \\
\hline izostanak str. pomoći & $-.17 * *$ & -.03 & $.12 * *$ & $-.09 *$ \\
\hline nedostatak udžbenika & -.02 & -.01 & -.06 & -.01 \\
\hline
\end{tabular}


Tablica 8. Vrijednosti provedene regresijske analize, standardizirani regresijski koeficijenti

\begin{tabular}{|c|c|c|c|c|}
\hline \multirow[t]{3}{*}{ Prediktori } & \multicolumn{4}{|c|}{ Kriteriji } \\
\hline & $\begin{array}{c}\text { potreba za stručnom } \\
\text { pomoći učiteljima u } \\
\text { inkluziji }\end{array}$ & $\begin{array}{c}\text { pesimizam za } \\
\text { uspješnu inkluziju }\end{array}$ & $\begin{array}{c}\text { doživljaj } \\
\text { kompetentnosti za } \\
\text { inkluziju }\end{array}$ & $\begin{array}{c}\text { problemi } \\
\text { suradnje s } \\
\text { roditeljima }\end{array}$ \\
\hline & $\mathbf{T}$ & $\mathbf{T}$ & $\mathbf{T}$ & $\mathbf{T}$ \\
\hline spol & $-2.73^{*}$ & $-3,40 * *$ & 1.48 & -.93 \\
\hline dob & -1.38 & $-3.55 * *$ & 1.01 & $-2.19 *$ \\
\hline stručna sprema & 1.92 & $1.99 *$ & $2.61 * *$ & 1.77 \\
\hline radno iskustvo & 1.25 & -.01 & .75 &,- 32 \\
\hline radno iskustvo s uč. s teškoćama & 1.52 & ,23 & $-3,36 * *$ &,- 75 \\
\hline prilagodba sadržaja & $-3.68 * *$ & $-3,00 * *$ & 1,35 & -1.61 \\
\hline IOOP & $-3.31 * *$ &,- 34 & 1,55 & $-2,16 *$ \\
\hline ocjenjivanje & -.24 & 05 & ,77 & $-1,72$ \\
\hline kontakt & -.19 & $-2.89 * *$ & .86 &,- 48 \\
\hline broj učenika & -.62 & -.38 &,- 79 & $-1,49$ \\
\hline izostanak str. pomoći & $-4,34 * *$ & -.54 & $3,28 * *$ & $-2,61 *$ \\
\hline \multirow[t]{2}{*}{ nedostatak udžbenika } & -.10 & -.88 & $-1,56$ & -.22 \\
\hline & $\begin{array}{c}\mathrm{R}^{2}=.10 \\
\Delta \mathrm{R}=.08 \\
\mathrm{~F}=4,74 * *\end{array}$ & $\begin{array}{c}\mathrm{R}^{2}=.11 \\
\Delta \mathrm{R}=.09 \\
\mathrm{~F}=5.64 * *\end{array}$ & $\begin{array}{c}\mathrm{R}^{2}=, 08 \\
\Delta \mathrm{R}=, 06 \\
\mathrm{~F}=3,68 * *\end{array}$ & $\begin{array}{c}\mathrm{R}^{2}=, 08 \\
\Delta \mathrm{R}=, 06 \\
\mathrm{~F}=3.62 * *\end{array}$ \\
\hline
\end{tabular}

Kazalo: $\mathrm{R} 2=$ koeficijent determinacije ; $\Delta \mathrm{R}=$ proporcija objašnjene varijance ; $\mathrm{t}$ (beta) = vrijednost t-testa vezanog uz značaj pojedinog pondera $; \mathrm{F}=\mathrm{F}$ omjer, ${ }^{* *} \mathrm{p}<0,01,{ }^{*} \mathrm{p}<0,05$

Trećim specifičnim ciljem nastojala se utvrditi mogućnost predviđanja četiriju stavova učitelja na osnovi njihovih demografskih i profesionalnih obilježja te iskazanih poteškoća u poučavanju učenika $\mathrm{s}$ teškoćama, a rezultati četiriju provedenih regresijskih hijerarhijskih analiza prikazani su u tablici 8. Predvidljivost stavova na osnovi ovog skupa prediktora je $6 \%$ do $9 \%$, što je nizak postotak varijabiliteta, koji, premda značajan, ukazuje na potrebu budućih istraživanja preostalog neispitanog prostora formiranja promatranih stavova. Analizirajući značajne prediktore potrebe za stručnom pomoći učiteljima u inkluziji, pokazalo se da se oni odnose na: spol i iskazane poteškoće u radu poput prilagodbe nastavnog sadržaja, izrade liste procjene i IOOP-a kao i izostanak stručne pomoći psihologa i edukacijskog rehabilitatora. Pesimizam za uspješnu inkluziju može se predvidjeti većom dobi učitelja i nižom stručnom spremom te iskazanim poteškoćama u poučavanju učenika s teškoćama kao što je prilagodba sadržaja i kontakt s učenicima s teškoćama. Na doživljaj kompetentnosti za inkluziju značajan doprinos ima niža stručna sprema, dulje iskustvo u radu s učenicima s teškoćama u razvoju i činjenica da učitelj iskazuje kako mu poteškoću u radu s učenicima s teškoćama ne zadaje izostanak stručne pomoći psihologa ili edukacijskog rehabilitatora. I na kraju, problemi suradnje s roditeljima su predvidljivi većom dobi učitelja i poteškoćama poučavanja učenika poput izrade liste procjene i IOOP-a, ali i izostanka stručne pomoći psihologa ili edukacijskog rehabilitatora.

Provedena je univarijatna analiza varijance razlikovanja učitelja u stavovima prema kriteriju predmeta koji predaju. Jedino se kod stava pesimizma za uspješnu inkluziju pokazalo kako se učitelji koji predaju različite predmete razlikuju (tablica 9).

Tablica 9. Temeljne vrijednosti univarijante analize varijance razlikovanja učitelja u stavovima prema kriteriju predmeta koji predaju

\begin{tabular}{|l|c|c|}
\hline Stavovi prema inkluziji & F omjer & Značajnost \\
\hline $\begin{array}{l}\text { Potreba za stručnom pomoći } \\
\text { učiteljima u inkluziji }\end{array}$ & 1.31 & .24 \\
\hline Pesimizam za uspješnu inkluziju & 2.35 & .00 \\
\hline $\begin{array}{l}\text { Doživljaj kompetentnosti za } \\
\text { inkluziju }\end{array}$ & 1.98 & .06 \\
\hline Problemi suradnje s roditeljima & 1.62 & .13 \\
\hline
\end{tabular}

Kako bi se utvrdile razlike između učitelja pojedinih predmeta (grupa predmeta) proveden je Post Hoc Bonferroni test uspoređujući svaki predmet sa 
svakim. Utvrđeno je da se međusobno razlikuju učitelji koji predaju društvene predmete s učiteljima koji predaju strukovne predmete i praktičnu nastavu, pri čemu su, kao što je vidljivo iz vrijednosti aritmetičkih sredina, učitelji strukovnih predmeta i praktične nastave pesimističniji za inkluziju od svojih kolega koji predaju društvene predmete (tablica 10).

Tablica 10. Aritmetičke sredine (M) $i$ standardne devijacije (SD) stava pesimizam za uspješnu inkluziju izražene za učitelje pojedinih predmeta uz primjenu Bonferironi test

\begin{tabular}{|l|c|c|c|}
\hline $\begin{array}{l}\text { Predmet koji učitelji } \\
\text { predaju }\end{array}$ & $\mathbf{M}$ & $\mathbf{S D}$ & $\mathbf{M}_{\text {DRUŠTVENI-OSTALI }}$ \\
\hline Hrvatski jezik & $\mathbf{3 . 0 5}$ & .81 & .29 \\
\hline strani jezik & 3.06 & .74 & .27 \\
\hline prirodni predmeti & 3.15 & .77 & .18 \\
\hline društveni predmeti & 3.33 & .81 & \\
\hline $\begin{array}{l}\text { Tjelesna i zdravstvena } \\
\text { kultura }\end{array}$ & 3.39 & .77 & -.04 \\
\hline strukovni predmeti & $\mathbf{2 . 7 5}$ & .86 & $.39^{*}$ \\
\hline praktična nastava & $\mathbf{2 . 7 1}$ & .70 & $.62^{*}$ \\
\hline struk. i praktična nastava & 2.94 & .92 & .59 \\
\hline
\end{tabular}

Dakle, kod samo jednog od promatrana četiri stava utvrđeno je razlikovanje učitelja prema predmetima.

\section{RASPRAVA}

Za više od pola učitelja strukovnih škola u Zagrebu poteškoću pri poučavanju predstavlja broj učenika u odjeljenju, a za skoro polovicu učitelja je prilagodba sadržaja, nedostatak udžbenika kao i podrške stručnog suradnika pri poučavanju učenika s teškoćama značajna poteškoća pri poučavanju. Približno trećini njih problem predstavlja ocjenjivanje ovih učenika. Rezultate treba promatrati u kontekstu da $22 \%$ ispitanika uopće nije imalo iskustva u radu s učenicima s teškoćama, što dodatno zabrinjava visokom razinom iskazanih poteškoća i sugerira da se učiteljima treba pružati sustavna pomoć u iskazanim problemima. Imajući u vidu da je od svih 25 škola iz istraživanja samo u jednoj bio zaposlen rehabilitator, a na tri škole i jedan socijalni pedagog, jasno je da učitelji strukovnih škola u Zagrebu u vrijeme provođenja istraživanja nisu dobivali adekvatnu pomoć u realizaciji inkluzije. Ove rezultate valja promatrati u kontekstu činje- nice da je nedostatak stručnjaka za teškoće kao što su intelektualne teškoće, specifične teškoće učenja, problemi u ponašanju i ADHD poremećaj, konstanta s kojom se učitelji u srednjim škola suočavaju kontinuirano već godinama, ne samo u Zagrebu nego u cijeloj Republici Hrvatskoj. I u tom kontekstu potrebno je pokušati razumjeti na koje su se sve načine učitelji prilagođavali nedostatku stručnjaka u uvjetima vanjskih zahtjeva da provode inkluziju (misli se na zakone i očekivanja javnosti) te formirali svoja uvjerenja i stavove i prema učenicima s teškoćama i prema inkluziji kao cilju, organizaciji i procesu. Zato, vrlo konkretno, nadovezujući se na utvrđene empirijske spoznaje, autorice ovog rada zagovaraju dodatna istraživanja za provjeru ovih podataka, politiku zapošljavanja stručnjaka edukacijsko-rehabilitacijskog profila u strukovnim školama te omogućavanje kontinuirane podrške centara potpore i stručnih timova. Kako bi se osigurala inkluzija u obrazovanju, važna je učinkovita potpora institucionalnih tijela i službi, zakonska podrška mobilnih timova i pomoćnika u nastavi, suradnja roditelja i škole (Igrić, Cvitković i Wagner Jakab, 2009; Igrić, Nikolić, Lisak i Rakić, 2010; Ivančić i Stančić, 2010; Ivančić i Stančić, 2013). U Hrvatskoj su se, temeljem iskustava svjetske i domaće teorije i prakse, počeli primjenjivati oblici podrške, kao što su mobilni stručni timovi i asistent u nastavi (Igrić, 2014). Transformacija posebnih ustanova u centre potpore je uobičajen trend u Europi, a većina zemalja izvještava o mreži inkluzivnih centara u svojim zemljama (Jablan i Kovačević, 2008). Ovi centri ostvaruju različite zadaće, a obzirom na svrhu istraživanja, autorice ovog rada ističu edukaciju učitelja, potporu pri ostvarivanju suradnje s roditeljima i pomoć u procjeni učenika te izradi IOOP-a i individualiziranih materijala za poučavanje kao najznačajnije oblike pružanja podrške učiteljima. Rezultati sugeriraju potrebu da se učiteljima na primarnoj i cjeloživotnoj razini obrazovanja osigura konkretna, kontinuirana i kvalitetna edukacija za poteškoće iz didaktičko-metodičke prilagodbe koje oni navode. Dakle, ovim se radom daje potpora dosadašnjim zaključcima da proces uključivanja valja unaprijediti kvalitetnijom preddiplomskom i diplomskom edukacijom učitelja, razvojem programa cjeloživotnog učenja te osiguravanjem primjerene edukacijsko-rehabilitacijske potpore (Kiš-Glavaš, 
Nikolić i Igrić, 1997; Stančić i sur., 2011; Tores, 1997, prema Igrić i sur. 2014).

Također, temeljem ovog istraživanja vrijedno je promišljati o standardima na razini strukovnih komora za prilagodbu sadržaja i normiranju razine ocjenjivanja učenika prema očekivanim kompetencijama profesije za koju se školuju kao i o poticajnim sredstvima motiviranja učitelja za izradu udžbenika za učenike s teškoćama. Interesantno je kako velika većina učitelja deklarativno iskazuje da kontakt s učenikom kao socijalni element ne predstavlja teškoću u tolikoj mjeri koliko svi ostali obrazovni elementi uključivanja za koje očekuju pomoć. U budućim bi istraživanjima mogli provjeriti zašto su didaktičko-metodički aspekti problem dok kontakt s učenikom nije i koje su aplikacije odgojno-obrazovnih ishoda i kasnije kompetentnosti i zapošljivosti za učenike s teškoćama u takvim okolnostima.

Prva i druga hipoteza, kojima su se pretpostavile relacije i prediktivne povezanosti između demografskih i profesionalnih obilježja učitelja kao i njihovih poteškoća u poučavanju učenika s teškoćama sa stavovima prema inkluziji, se djelomično potvrđuju. Gotovo svi dobiveni rezultati podupiru početne pretpostavke, osim nalaza o ženskom spolu za dva stava. Naime, suprotno od očekivanog, ženski su ispitanici iskazali stav potrebe za većom pomoći u inkluziji i iskazali veći pesimizam za inkluziju. Podaci prema kojima ženski ispitanici iskazuju veću potrebu za stručnom podrškom ali i veći pesimizam impliciraju na mogući pritisak radi osjećaja većeg osjećaja stresa kod žena koji je primjećen u nekim radovima u svijetu. Forlin (2001, prema Kranjčec Mlinarić, Žic Ralić i Lisak, 2016) u Australiji utvrđuje da je učiteljima stresno poučavati individualno učenika s teškoćama učenika u inkluzivnom razredu, pri čemu su žene pokazale znatno veći stupanj stresa, nego muškarci. Učitelji ženskog spola su u prosjeku emocionalno iscrpljenije od svojih muških kolega (Antoniou, Ploupi i Ntalla, 2013, Burke Greenglass 1993, Grusel, Sunbul i Sari, 2002, Sari, 2004., sve prema Slišković, Burić i Knežević, 2016). Značajnim se pokazalo da žene (učiteljice) u usporedbi s muškarcima u znatno većoj mjeri podliježu obrascima napora i sagorijevanja (Schaarschmidt, 2005, prema Foro, 2015). Imajući u vidu navedeno, pod- sjećamo da se stavovi mjereni u ovom istraživanju formiraju u kontekstu nepostojanja dovoljnog broja adekvatnih stručnih suradnika u školi i mogućeg predviđanja učitelja da će tako i ostati u dogledno vrijeme. Jesu li muškarci u takvim okolnostima pomireni sa stanjem u kojem rade, pa pomoć niti ne očekuju niti ne traže? Ovo su također pitanja za buduća istraživanja.

Obilježja učiteljeve dobi, njegove duljine radnog staža $i$ iskustva u radu s učenicima s teškoćama potvrđuju početne pretpostavke (Van Reusen, Shoho i Barker, 2001; Dulčić i Bakota, 2008). Razumljivo je da iskustvo donosi veći osjećaj kompetentnosti i sigurnosti u radu. Stjecanje iskustva u radu s učenicima s teškoćama studiranjem nije dovoljno sustavno regulirano. Moguće je da bi bilo vrijedno svim studentima učiteljskih studija na svim razinama (razrednoj i predmetnoj nastavi) pravovremeno već tijekom studiranja sustavno osigurati iskustva volontiranja ili studentske prakse $\mathrm{s}$ učenicima s teškoćama jer bi se iskustvenim učenjem vjerojatno bolje pripremali za budući samostalni rad s tim učenicima.

Očekivano je i također i objašnjivo kako će veću stručnu pomoć u inkluziji trebati oni učitelji koji uočavaju teškoće u prilagodbi sadržaja, izradi IOOP-a i izostanku stručne pomoći. Kao što primjećuju Mešalić, Mahmutagić i Hadžihasanović (2004), uključivanjem stručnog suradnika (edukacijskog rehablilitatora) u proces poučavanja bi se osigurala neizostavna stručna podrška i pomoć učenicima na području svladavanja školskih programa i socijalizacije, savjetodavna pomoć roditeljima i pomoć učiteljima u otklanjanju brojnih prepreka $\mathrm{u}$ inkluzivnom procesu. Upravo oni učitelji koji nemaju suradnju s edukacijskim rehabilitatorom ili nemaju zaposlenog edukacijskog rehabilitatora u školi, najviše ističu potrebu za dodatnom edukacijom i edukacijsko-rehablitacijskom potporom (Igrić i sur., 2014) pa se može reći da ovaj rezultat dodatno daje potvrdu već uočenoj potrebi za stručnom podrškom učiteljima u inkluziji.

Nadalje, veći pesimizam za uključivanje imaju stariji učitelji s nižom stručnom spremom kojima kontakt s učenicima s teškoćama i prilagodba sadržaja predstavljaju probleme. U budućim bi istraživanjima valjalo provjeriti radi li se o grupi učitelja s usvojenim stereotipima i predrasudama koje je 
moguće mijenjati pozitivnim iskustvima i u starijoj dobi, premda za takve intervencije škola treba osigurati vrijeme i organizacijske resurse. Ukoliko neki stariji i niže obrazovani učitelji imaju autoritarne odgojne pristupe, može se implicirati da primjenjuju prijekorne, pesimističke i represivne procjene učenika o kojima govore Austin i Cage (1980, prema Ivančić i Stančić, 2013), što može biti prepreka inkluziji jer može izazvati teškoće, pristranost i nezadovoljstvo u razredu. Ukoliko je riječ o navedenim profesionalnim deficitima komunikacije i interakcije ${ }^{6}$, svakako bi se trebalo dati ovoj skupini učitelja podrška i edukacija o suvremenim komunikacijskim pristupima s učenicima, a osobito s učenicima koji možda imaju probleme u socijalnoj interakciji radi svojih teškoća. Sve navedene implikacije također treba provjeriti u budućim istraživanjima i temeljiti ih na spoznajama da pozitivni stavovi spram inkluzije i dobre stručne kvalifikacije učitelja određuju učinkovitost inkluzije i uspjeh učenika s teškoćama u školi (Avramidis i Norwich, 2002; Kudek-Mirošević i Jurčević-Lozančić, 2014).

Zanimljivo je da veći osjećaj kompetentnosti u inkluziji imaju učitelji s nižom stručnom spremom koji imaju dulje iskustvo u radu s učenicima s teškoćama u razvoju te im izostanak stručne pomoći nije problem. Rezultat vezan uz prediktor duljine iskustva je očekivan jer učitelji koji provode inkluzivne programe nekoliko godina imaju pozitivnije stavove nego učitelji koji su imali malo ili nemaju takvog iskustva. Ovo je vrlo logično imajući u vidu da upravo iskustvo rada s učenicima s teškoćama, pogotovo ukoliko su ishodi pozitivni, daje snažan osjećaj uvjerenja u vlastite sposobnosti, pa u tom slučaju učitelj smatra da mu dodatna pomoć nije potrebna. Ostaje otvoreno pitanje koliko su realne ove kompetencije koje učitelji osjećaju uslijed svog iskustva i možda samopouzdanja, no svakako je dobro da se kod učitelja gradi povjerenje u vlastite mogućnosti i vještine kako bi bili što samostalniji u pripremi i realizaciji inkluzivnog okruženja.

Rezultati pokazuju kako će vjerojatno veće probleme suradnje s roditeljima imati stariji učitelji i kao i oni koji imaju problem s listama procjene $\mathrm{i}$ izradom IOOP-a te trebaju dodatnu pomoć psihologa ili rehabilitatora. Sve navedeno upućuje na to da se radi o skupini učitelja koji, premda imaju puno životnog iskustva, u svojim prethodnim edukacijama $i$ iskustvima nisu izgradili niti vještine izrade individualiziranih materijala niti povjerenje u svoje komunikacijske kompetencije pa se trebaju oslanjati na stručnog suradnika u komunikaciji s roditeljima odnosno, trebaju stručnu pomoć i posredovanje. Radi li se ovdje o izostanku emocionalne i socijalne kompetentnosti za zahtjevne situacije koje su vrlo česte u radu s roditeljima učenika s teškoćama, odnosno propusta sustava da educira ove ljude jest opet pitanje za buduća istraživanja. Također, moguće je da na navedene probleme suradnje s roditeljima može utjecati i emocionalna iscrpljenost koju nosi životna dob. Prema dobivenim rezultatima ovog rada, u srednjim strukovnim školama postoji skupina starijih učitelja kojima je veoma važno ponuditi programe osnaživanja u vještinama uspostavljanja odnosa s roditeljima kao sudionicima planiranja i izrade IOOP-a te izgrađivati povjerenje $\mathrm{u}$ vlastite kapacitete i kompetentnost za inkluziju.

Treća je hipoteza kojom se pretpostavilo da učitelji koji predaju strukovne predmete i praksu imaju nepovoljnije stavove prema inkluziji djelomično prihvaćena. Rezultati pokazuju da su oni iskazali veći pesimizam za uspješnu inkluziju nego učitelji društvenih predmeta. Predmeti struke su specifični i radi toga što učenici trebaju pokazati konkretne vještine i psihosocijalnu zrelost za kompetentno obavljanje konkretnih zadataka izvedbe, pa se rezultati mogu promatrati i u kontekstu učiteljevih niskih očekivanja stjecanja pojedinih kompetencija. Rezultati upućuju na veću potrebu za edukacijom i stručnom podrškom upravo ciljanoj skupini nastavnika koji predaju stručne predmete $\mathrm{i}$ vode praksu, a prema demografskim pokazateljima, vjerojatno se radi o starijim učiteljima niže stručne spreme i ženskog spola.

\section{ZAKLJUČCI I PREPORUKE}

Cilj ovog rada bio je ispitati demografske i profesionalne karakteristike učitelja strukovnih škola $\mathrm{u}$ iskazivanju stavova prema uključivanju učenika

6 Prema Okviru nacionalnoga standarda kvalifikacija za učitelje u osnovnim i srednjim školama, socijalne i komunikacijske kompetencije su ključne kompetencije učitelja jer ,posebno je naglašena važnost komunikacijskih i socijalnih vještina ključnih za funkcioniranje u profesionalnoj zajednici, ali i društvenome okruženju“ http://nvoo.hr/?page_id=391 (pribavljeno 13.4.2017.) 
s intelektualnim teškoćama, specifičnim teškoćama učenja, problemima u ponašanju i ADHD poremećajem, dok je aplikativna svrha realizacije cilja bila predlaganje subjektivnih i objektivnoorganizacijskih elemenata poboljšanja u školi te dodatnih edukacija za učitelje radi uspješnog uključivanja učenika s navedenim teškoćama. Prema osnovnim rezultatima istraživanja ${ }^{7}: 1$.) otprilike jedna trećina do polovine učitelja samoiskazuje teškoće u poučavanju učenika s teškoćama na način da im poteškoću predstavljaju prilagodba sadržaja pojedinom učeniku, izrada liste procjene i IOOP-a, ocjenjivanje učenika s teškoćama, broj učenika u razrednom odjeljenju, izostanak stručne pomoći psihologa, edukacijskog rehabilitatora i sl. te nedostatak udžbenika za učenike s teškoćama. Istovremeno, velikoj većini učitelja kontakt s učenikom s teškoćama ne predstavlja problem; 2) stavovi učitelja prema uključivanju mogu se predvidjeti nekim demografskim i profesionalnim obilježjima kao i nekim navedenim teškoćama u radu, no ta predvidljivost slabo objašnjava promatrani prostor predikcije; 3 ) potreba za stručnom pomoći učiteljima u inkluziji može se predvidjeti ženskim spolom i teškoćama prilagodbe nastavnog sadržaja, izradom liste procjene i IOOP-a kao i izostankom stručne pomoći psihologa i edukacijskog rehabilitatora; 4) optimizam za uspješnu inkluziju može se predvidjeti nižom dobi učitelja i višom stručnom spremom te odsustvom poteškoća u prilagodbi sadržaja i kontaktu s učenicima s teškoćama; 5) doživljaj kompetentnosti za inkluziju može se predvidjeti nižom stručnom spremom, duljim iskustvom u radu s učenicima s teškoćama i činjenicom da učitelj iskazuje kako mu poteškoću u radu s učenicima s teškoćama ne zadaje izostanak stručne pomoći psihologa ili edukacijskog rehabilitatora; 6) problemi suradnje s roditeljima mogu se predvidjeti većom dobi učitelja i teškoćama izrade liste procjene i IOOP-a, ali i izostankom stručne pomoći psihologa ili edukacijskog rehabilitatora; 7) učitelji društvenih predmeta imati optimističnije stavove za uspješnu inkluziju od učitelja strukovnih predmeta i učitelja praktične nastave .

U raspravi se otvaraju nova istraživačka pitanja, a kao metodološka ograničenja se navodi da nije obuhvaćen dovoljan broj potencijalnih prediktora za mjerenje stavova te bi u budućim istraživanjima trebalo utvrđivati i specifičnosti samih učenika i njihovih roditelja, a možda i osobitosti kvalifikacija za koje se obrazuju. Osim toga, istraživanje je provedeno s učiteljima glavnog grada, dok bi bilo zanimljivo utvrditi stavove na reprezentativnom uzorku za Hrvatsku i napraviti analize vezane uz sociološke varijable. Mjerni instrument za poteškoće u poučavanju učenika s teškoćama se može doraditi linearnim semiintervalnim mjernim mehanizmom i dodatnim česticama.

Vezano uz aplikativnu svrhu istraživanja, iz dobivenih rezultata istraživanja i uz oslonac na prethodne radove, mogu se implicirati potrebe za:

1. smanjenjem broja učenika s teškoćama unutar razrednih odjela, odnosno usklađivanjem s odredbama Državnog pedagoškog standarda srednjoškolskog sustava odgoja i obrazovanja (NN 63/2008);

2. rekonceptualizacijom postojećih modela edukacije budućih učitelja;

3. uspostavom kontinuirane stručne potpore inkluziji.

7 Radi usmjerenosti na pozitivne ishode, dajemo rezultate koji govore o optimizmu, a ne pesimizmu za uspješnu inkluziju na način da su se promjenili smjerovi dobivenih prediktora. 


\section{LITERATURA:}

Avramidis, E., Norwich, B. (2002). Teachers' attitudes towards integration/inclusion: a review of the literature. European Journal of Special Needs Education, 17( 2), 129-147.

Bartolac, A. (2013). Socijalna obilježja svakodnevnog života djece i mladih s ADHD-om. Ljetopis socijalnog rada, 20(2), 269-300.

Billingsley, B. S., Fall, A., \& Williams, T. O., (2006). Who Is Teaching Students with Emotional and Behavioral Disorders?: A Profile and Comparison to Other Special Educators. Behavioral Disorders, 1(3), 252-264.

Bouillet, D., Bukvić, Z. (2015): Razlike u mišljenjima studenata i zaposlenih učitelja o obrazovnoj inkluziji učenika s teškoćama. Hrvatska revija za rehabilitacijska istraživanja, 51(1), 9-23.

Bouillet, D. (2010). Izazovi integriranog odgoja i obrazovanja. Zagreb: Školska knjiga.

Bowman, I. (1986). Teacher training and the integration of handicapped pupils: some findings from a fourteen nation UNESCO study. European Journal of Special Needs Education, 1( 1), 29-38.

Brook, U., Watamberg, N., \& Geva, D. (2000): Attitude and knowledge of attention deficit hyperactivity disorder and learning disability among high school teachers. Patient Education and Counseling, 40, 247-252.

Chazan, M. (1994): The attitudes of mainstream teachers towards pupils with emotional and behavioural difficulties. European Journal of Special Needs Education, 9(3), 261-274.

Clough, P., Lindsay, G. (1991): Integration and the Support Service: Changing Roles in Special Education. Windsor, England: NFER - Nelson.

Državni pedagoški standard srednjoškolskog sustava odgoja i obrazovanja; Narodne novine, br. 63/2008.

Dulčić, A., Bakota K. (2008). Stavovi učitelja povijesti redovnih osnovnih škola prema integriranim učenicima oštećena sluha i učenicima s poremećajima govorno-glasovne komunikacije te specifičnim teškoćama u učenju. Hrvatska revija za rehabilitacijska istraživanja, 44(2), 31-50.

Đević, R. (2009). Spremnost nastavnika osnovne škole da prihvate učenike sa teškoćama u razvoju. Zbornik Instituta za pedagoška istraživanja, 41, 367-382.

Florian, L. (2010). The concept of inclusive pedagogy. U: Hallet, G i Hallet, F. (ur.): Transforming the role of the SENCO. (str. 61-72). Buckingham: Open University Press.

Florian, L., Linklater, H. (2010). Preparing Teachers for Inclusive Education: Using Inclusive Pedagogy to Enhance Teaching and Learning for All. Cambridge Journal of Education, 40(4), 369 - 386.

Foro, D. (2015). Profesionalne kompetencije nastavnika u suočavanju sa stresnim situacijama u školi. Doktorski rad. Filozofski fakultet Sveučilišta u Zagrebu.

Fulgosi-Masnjak, R. (2013). Roditeljsko poimanje tolerancije i primjena tolerancije u odgoju djece i suradnji s učiteljima. Hrvatska revija za rehabilitacijska istraživanja, 49, supplement, 23-36.

Igrić, Lj. (2015): Osnove edukacijskog uključivanja. Zagreb: Školska knjiga.

Igrić, Lj., Cvitković D., Wagner-Jakab, A. (2009). Djeca s teškoćama u interaktivnom sustavu obitelj - škola - vršnjaci. Hrvatska revija za rehabilitacijska istraživanja, 45(1), 31-38.

Igrić, Lj., Fulgosi-Masnjak, R., Wagner Jakab, A. (2014). Učenik s teškoćama između škole i obitelji. Zagreb: Centar inkluzivne potpore IDEM.

Ivančić, Đ., Stančić, Z. (2004). Roditelji - suradnici škole. U: Igrić, Lj. (ur): Moje dijete u školi, priručnik za roditelje. (str. 65-85). Zagreb: Hrvatska udruga za stručnu pomoć djeci s posebnim potrebama IDEM.

Ivančić, Đ., Stančić, Z. (2013). Stvaranje inkluzivne kulture škole. Hrvatska revija za rehabilitacijska istraživanja, 49(2), 139-157. 
Kiš-Glavaš, L., Cvitković D. (2014). Učitelji i edukacijsko uključivanje. U: Igrić, Lj., Fulgosi-Masnjak, R., WagnerJakab, A.(ur.): Učenik s teškoćama između škole i obitelji. (str. 28-40). Zagreb: Centar inkluzivne potpore IDEM.

Kiš-Glavaš, L., Nikolić, B., Igrić, Lj. (1997). Stavovi učitelja prema integraciji učenika usporenog kognitivnog razvoja. Hrvatska revija za rehabilitacijska istraživanja, 33(1), 63-75.

Kranjčec Mlinarić, J., Žic Ralić, A., Lisak, N. (2016). Promišljanje učitelja o izazovima i barijerama inkluzije učenika s poteškoćama u razvoju. Školski vjesnik: časopis za pedagogijsku teoriju i praksu, 65, Tematski broj, 233-247.

Kudek Mirošević, J., Jurčević Lozančić, A. (2014). Stavovi odgajatelja i učitelja o provedbi inkluzije u redovitim predškolskim ustanovama i osnovnim školama. Hrvatska revija za rehabilitacijska istraživanja, 50(2), 17-29.

Kudek Mirošević, J, Opić, S. (2011). Handling Students with ADHD Syndrome in Regular Elementary Schools. Napredak, 15(1), 75-92.

Kuvač, J., Vancaš, M. (2003). Učiteljska uloga i znanje - ključ uspješnog rada. U: Pavličević-Franić, D.; Kovačević, M. (ur.): Komunikacijska kompetencija u višejezičnoj sredini II. (str. 64 -73). Zagreb: Slap i Sveučilište u Zagrebu.

Levin, H. (1992). Accelerated Schools for At-risk Students. New Bruinswick, N.J.: Center for Policy Research in Education, Rutgers University.

Lewis, R.B., Doorlag, D.H. (1987). Teaching special students in the mainstream. Ohio: Merrill Publishing Company.

Lifshitz, H., Glaubman, R., Issawi, R. (2004). Attitudes towards inclusion: the case of Israeli and Palestinian regular and special education teachers. European Journal of Special Needs Education, 19(2),171-190.

Lord-Nelson, L. G. L., Summers, J. A., \& Turnbull, A .P. (2004): Boundaries in family-professional relationships: Implications for special education. Remedial and Special Education, 25, 153-165.

Mavrin-Cavor, Lj., Levandovski, D. (1991). Istraživanja pretpostavki i efekata integracije učenika s mentalnom retardacijom u redovne uvjete odgoja i obrazovanja u Hrvatskoj. Primijenjena psihologija, 12(1-2), 41-54.

Međimorec Grgurić, P., Vlah, N., Baftiri, Đ., Martinić, T., Šaka, D. (2014). Stavovi nastavnika srednjih strukovnih škola o integraciji učenika s intelektualnim teškoćama, specifičnim teškoćama učenja, problemima u ponašanju i ADHD-om. U: Žic-Ralić, A., Bukvić, Z. (ur), Zbornik sažetaka i radova 10. kongresa edukacijskih rehabilitatora s međunarodnim sudjelovanjem Poticajno okruženje za cjeloživotno učenje (str.34-49), Varaždin: Savez edukacijskih rehabilitatora Hrvatske.

Mejovšek, M. (2013). Metode znanstvenog istraživanja u društvenim i humanističkim znanostima. Zagreb: Naklada Slap.

Mešalić, S., Mahmutagić, A., Hadžihasanović, H. (2004). Edukacija i socijalizacija učenika usporenog kognitivnog razvoja. Tuzla: Defektološki fakultet Univerzitet u Tuzli.

Mustać,V., Vicić, M. (1996): Rad s učenicima s teškoćama u razvoju u osnovnoj školi - priručnik za prosvjetne djelatnike. Zagreb: Školska knjiga.

Pravilnik o osnovnoškolskom i srednjoškolskom odgoju i obrazovanju učenika s teškoćama u razvoju: Narodne novine, br. 24/2015.

Salend, S. J., Duhaney, L. M. G. (1999): The impact of inclusion on students with and without disabilities and their educators. Remedial and Special Education, 20(2), 114-126.

Schmidt, M., Vrhovnik, K. (2015). Attitudes of Teachers Towards the Inclusion of Children with Special Needs in Primary and Secondary Schools. Hrvatska revija za rehabilitacijska istraživanja, 51(2), 16-30.

Sekušak-Galešev, S. (2008). Samopoimanje djece s posebnim potrebama u uvjetima edukacijske integracije. Doktorska disertacija. Edukacijsko-rehabilitacijski fakultet Sveučilišta u Zagrebu.

Skočić-Mihić, S., Gabrić, I., Bošković, S. (2016). Učiteljska uvjerenja o vrijednostima inkluzivnog obrazovanja. Hrvatska revija za rehabilitacijska istraživanja, 52(1), 30-41. 
Skočić-Mihić, S., Lončarić, D., Kolombo, M., Perger, M., Nastić, M., Trgovčić, E.: Samoprocijenjene kompetencije studenata učiteljskog studija za rad s djecom s posebnim odgojno-obrazovnim potrebama. Napredak, 154(3), 303-322.

Slišković, A., Burić, A., Knežević, A. (2016): Zadovoljstvo poslom i sagorijevanje na poslu kod učitelja: važnost podrške ravnatelja i radne motivacije. Društvena istraživanja, 25(3), 371-392.

Stančić, V. (1985). Djeca s teškoćama u razvoju u redovnoj školi. Zagreb: Savez slijepih Hrvatske i SIZ odgoja i osnovnog obrazovanja.

Škutor, M. (2014): Partnerstvo škole i obitelji-temelj dječjeg uspjeha. Napredak, 155(3), 209-222.

Thousand, J. S., Villa, R. A., \& Nevin, A. I. (1994). Creativity and Colaborative Learning: A practical Guide to Empowering Students and Teachers. Baltimore: Paul H. Brookes

Tomplison, S. (1982): A sociology of special education. Boston: Routledge \& Kegan Paul.

Van Reusen, A. K., Shoho, A. R., \& Barker, K. S. (2001). High School Teacher Attitudes Toward Inclusion. High School Journal, 84(2), 7-14.

Zakon o odgoju i obrazovanju u osnovnoj i srednjoj školi: Narodne novine, 87/08, 86/09, 92/10, 105/10, 90/11, 16/12, $86 / 12,126 / 12,94 / 13,152 / 14,7 / 2017$.

\section{RELATIONSHIP OF DEMOGRAPHIC AND PROFESSIONAL CHARACTERISTICS OF VOCATIONAL SCHOOL TEACHERS TO THEIR ATTITUDES TOWARDS EDUCATIONAL INCLUSION}

\footnotetext{
Abstract: Teachers are key actors in promoting inclusion primarily because of their readiness to accept students with disabilities, and the resulting engagement between student and teacher can strongly influence whether inclusion is successful. The present study explored whether demographic and professional characteristics of vocational school teachers influence their attitudes towards inclusion of students with intellectual disability, specific learning disabilities, behavioral problems and attention deficit hyperactivity disorder. The following data were collected on 568 teachers (33\% male, $M=45$ yr) from 25 vocational schools in Zagreb, Croatia: gender, age, qualifications, subject area, overall work experience, work experience with students with disabilities, and self-reported difficulties working with students with disabilities. The occurrence of these factors was analyzed relative to the following four outcomes: teacher's need for professional assistance in achieving inclusion, pessimistic attitude of the teacher about likelihood of successful inclusion, self-perceived competence in achieving educational inclusion, and problems in collaborating with parents. The results suggest that certain demographic and professional factors in teachers are associated with their attitudes towards inclusion of students with disability. Further research is needed on this issue, which should ultimately lead to the design of lifelong-learning interventions that nurture in teachers greater eagerness to work with students with disability.
}

Key words: attention deficit hyperactivity disorder, behavioral problems, high school, teacher attitudes, learning difficulties 